\title{
SEMINAR
}

on

\section{VIOLENCE AGAINST WOMEN and GIRLS}

Presentation on the Kathmandu Meeting and

Kathmandu Commitment

\author{
Organized by \\ ACBAR Women Affairs Sub-Committee \\ Executive Guest House, Abdara Road, Peshawar
}

27 November 1997

Prepared by: Belquis R.A.

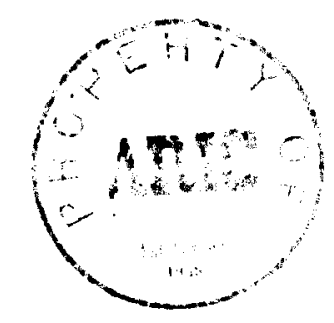




\section{CONTENTS}

PART ONE

PART TWO

PART THREE

Annexes
Background and Program of the Seminar

Presentation on the Kathmandu Meeting 1

Objectives by Belquis 2

Contents by Palwasha 2

Methodology by Niloufar 5

Comments from Participants of Peshawar Seminar

List of Participants

Resource materials available

Feedback Form

Kathmandu Commitment

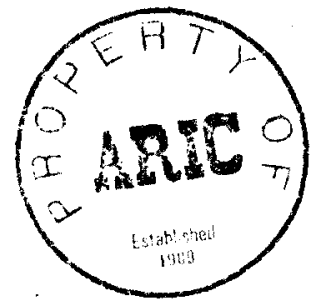




\section{SEMINAR ON ENDING DOMESTIC VIOLENCE 27 NOVEMBER 1997 \\ Organized by ACBAR, Women Affairs Sub-Committee}

PART ONE - Background and Programme

In order to express our solidarity with women suffering from Domestic Violence worldwide and to share information from the UNICEF Regional Meeting on "Ending Violence against Women and Girls in South Asia", which took place in Kathmandu, Nepal from 21 to 24 October 1997, ACBAR Women Affairs Sub-Committee organized a one day seminar in Executive Guest House on 27 November.

Around 32 women and men from different aid agencies and teachers from refugees schools participated at the seminar.

The seminar commenced with the recitation of a few verses from the Holy Quran by Malalai.

The seminar proceeded according to the already prepared agenda.

PART TWO - Presentation about the Kathmandu Meeting

Belquis opened the seminar by welcoming the participants, and outlined:

Days to Remember

- 16 Days of Action against Gender Violence, November 25- December 10, have been announced by the Center for Women's Global Leadership at Rutgers University.

November 25 is International Day against Violence against Women, declared in 1981 in Bogota, by the first Feminist Encuentro for Latin America. On that date two sisters were critically murdered by the Trujillo dictatorship of the Dominican Republic.

December 10 celebrates the anniversary of the Universal Declaration of Human Rights, proclaimed in 1948.

(a) The Kathmandu Meeting on "Ending Violence against Women and Girls in South Asia"

The meeting was organized based on the recognition that violence against women and girls is a prevalent phenomenon in the region, as well as at the global level, and needs to be addressed effectively and at various levels. Gender violence adversely impacts the lives of affected women, as well as those of their children, the family unit, communities and the national development process in general. This matter has been substantiated by considerable research, primarily by women activists of the regional countries. Very important is also the fact that violence against women and girls is against the human rights of women and children, as reflected in CEDAW ${ }^{1}$ and $\mathrm{CRC}$, both ratified by all the member states of this Region.

Signed but not ratified by Afghanistan. 
The South Asia region has demonstrated its strength and commitment to gender equality and activism over the years.

It is based on the above context that the UNICEF Regional Office for South Asia (ROSA) decided to organize a regional meeting on violence against women and girls in South Asia with the support of UNIFEM, UNDP, UNFPA, WHO and the Swiss Development Fund.

The objectives of the meeting were:

1) Exchange of successful actions and strategies against violence to women and girls in South Asia.

2) Increased involvement of men as part of the solution rather than as perpetrators of violence to women and girls in south Asia.

3) Partnerships to address and prevent the impact of domestic violence on children and youth.

4) Greater awareness of resources which can be used to stop violence against women and girls.

5) Plans for greater cooperation and re-vitalized movement against such violence.

Over 120 women and men representing countries of South Asia (Bangladesh, India, Pakistan, the Maldives, Nepal, Sri Lanka and Afghanistan) came together in Kathmandu, Nepal, from 21-24 October, 1997 to attend a historic Meeting organized by the UNICEF ROSA on ending violence against women and girls. The wide range of participants included national and international NGO leaders and members; human, women's and child right activists; academics, legal and medical professionals; supreme court barristers, senior police officials; members of parliament; media representatives and artists. They had come together to break the silence on violence against women and girls.

\section{(b) Contents of the Meeting by Palwasha Hassan:}

The Kathmandu Commitment was developed and agreed upon at the meeting as an indication of

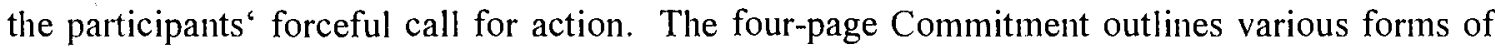
violence against women, all embedded within the patriarchal structure of gender inequality. It notes that such violence is against the human' rights of women and girls, as spelled out in various Conventions and Agreements, in particular the Convention on the Rights of the Child (CRC) and the Convention on Elimination of All Forms of Discrimination Against Women (CEDAW). A Dari translated copy of Kathmandu Commitment was distributed to the participants of the seminar. The Pashtu copy will be ready within two weeks.

The delegates and participants of the Meeting committed themselves to actively participate in the international 16 days' Campaign (25 November-10 December 1997) on women's rights, with a focus on ending violence against women and girls. In this regard, agreements were reached that on the $27^{\text {th }}$ of November 1997 they would focus on domestic violence. Various national marches will be held during this period advocating greater representation of women in the decisionmaking process, an issue closely linked to the greater empowerment of women and stopping gender violence. The rights of girls will be highlighted on yet another day during this period.

The meeting recognized that attitudinal and behavioral change needs to begin through an internalization process as well as personal commitment. It was for this reason that the 
participants each prepared individual pledges, challenging themselves the strength and drive of the participants and serve as an example of the need to combat violence against women and girls at various levels.

\section{Action Recommended in the plenary Sessions}

1) Building Coalitions to End Violence Against Women and Girls: Lessons-Learned, Questions and New Possibilities

- bringing together committed individuals, forming structures such as NGOs

- forging alliances of various NGOs in a Network to address and stop violence against women and girls

- activists to form coalitions in lobbying with their Government and holding them accountable to international Conventions such as CRC and CEDAW.

2) Impact of Gender violence on Children

- conducting quantitive and qualitative research and how it impact girls differently from boys

- breaking the silence on these subjects by activists from various professional backgrounds and acting with fearless conviction

- increasing public awareness and in particular the awareness of parents on the need to address cases of child abuse when and where they occur

- facilitating parents' and children's access to support services(clinical, psychological)

- sensitizing/training medical profession on child abuse and gender violence

- organizing preventive action at all levels

- re-examining cultural norms, in particular those pertaining to marital relations and the rights of husbands

- holding Governments responsible in addressing gender violence and protecting women and children under such circumstances

3) Challenging Gender Role Stereotypes: Towards a new model of masculinity

- researching, understanding and changing existing male cultures, value-systems, behaviors and stereotypes

- recognizing the link between gender violence, concepts of masculinity, patriarchy and public power relations

- refraining from simplistic approaches to providing alternative models of masculinity

- encouraging new positive models of masculinity to be developed, parallel to new models of femininity (through the education system and media)

- breaking gender stereotypes

- recognizing and acknowledging the growing number of activist men involved in the struggle to end gender violence and forging alliances with them 
4) working with media and arts in coalition against violence to women and girls

- benefiting from cultural activism in addressing gender violence

- recognizing role of artistic work in internalizing behavioral changes and questioning existing value-system

- encouraging and using innovative means of artistic expression on gender violence which are culturally acceptable and possible under various political situations

- acknowledging positive as well as negative role of the media in addressing gender violence and adopting effective media strategies

- countering the ever-growing sensationalism and profit-orientation of the media by provision of gender sensitization to journalists, forging of alliances with gender sensitive journalists and the development of alternative media outlets

- activists need to be cautious in their use of mainstream media.

5) Working with Youth against gender violence in South Asia

- providing gender sensitization, as well as training/counseling on gender violence to schoolaged children, youth, their teachers and parents

- developing relevant and suitable training material and training enough male and female resource persons

- involving children and youth in the movement against violence

- listening to children and youth and benefiting from their support, energy and creativity

- benefiting from youth in adult education as well as community action against gender violence

6) successful community action to end violence against women and girls in south Asia

- developing innovative communication material to address gender inequality in communities

- integrating community organization and empowerment with legal literacy, health care and income generation activities for women

- organizing community men in support of women's empowerment and stopping gender violence

- establishing community-based but non-sectarian community organizations to address gender violence in general as well as gender violence linked to sectarian differences

- establishing community-based support system for victims of violence (counseling, legal support, protection)

- mobilizing communities in holding their governments accountable for the safety of women and girls.

7) using the legal' system to end violence against women and girls in South Asia

- establishing women's police units

- sensitizing law enforcement officers and medical professionals

- studying laws and legal procedures, identifying gaps, lobbying for legal and procedural changes and reforms

- enforcing gender-sensitive laws 
- ensuring punishment of perpetrators

- ensuring abused women do not suffer further in the course of trial procedures

- enhancing co-ordination between medical and legal professionals dealing with abuse cases

- improving the skills of the medico-legal professionals and supporting their work

- adopting a multi-sectoral approach to dealing with cases of abuse.

8) re-examing the women's movement against gender violence: success and actions still needed

- strengthening the women's movement's role in ending gender violence

- continuing with action-oriented research on violence against women and girls for advocacy, policy-making and planning purposes

- increasing awareness-raising advocacy/training on gender equality

- enhancing internal as well as other alliances (human rights activists, artists, media, lawyers, doctors and in particular with women at the grassroots)

- providing legal literacy and gender sensitization training by women's groups, to women, men and various professional groups

- establishing more centers for the referral of abused women

\section{(c) Methodology of the Meeting by Niloufar Pourzand:}

The meeting's methodology was participatory and action oriented. It was based on a recognition that iner-linkages between research, lobbying for policy and legal changes and grassroots-level action exist and need to be strengthened and highlighted.

Eight plenary sessions were held, covering the importance of coalition building, impact of gender violence on children, challenging gender stereotypes and providing new models of masculinity, successful community action, working with youth, media and arts, using the legal system and the role of the women's movement.

In consultation with the participants, a number of areas were chosen for group work. These were felt to be the most important sites where gender violence takes place. In these group work session, experiences were shared and relevant action points developed. The following themes were covered :

- family

- community

- school

- media

- legal system

- health system

\section{(d) Film on Domestic Violence (Voice of Change)}

Different types of Violence against Women and Girls from various countries in South Asia were exhibited. 
The "Voice for Change" movie is available to be borrowed.

PART THREE - Peshawar Participants' Comments

Recommendations from the participants of the Seminar:

- The movie should be rendered into Dari/Pashtu language

- The need for a wider participation of women and men in such seminars and meetings

- Media should address the Violence against Women and Girls

- Document Violence against Women in Afghanistan and collect testimonies

- Translation of relevant material for working inside Afghanistan

- Follow up actions by AWN

Copies of Questionnaire on Personal Interest and Knowledge of Violence Against Women were distributed to the participants, who were asked to complete it and return to Belquis in ACBAR office by 4 December 1997. 


\section{List of Participants}

\begin{tabular}{|c|c|c|c|c|}
\hline$S N$ & Contact & Agency & Address & Phone \\
\hline 1. & Belquis R.A. & ACBAR & 2 Rehman Baba Road, U/T & 40839 \\
\hline 2. & Diana Poya & ACBAR & 2 Rehman Baba Road, U/T & 40839 \\
\hline 3. & Farangis & Afghanaid & 5B, Gul Mohar Road, U/T & 841083 \\
\hline 4. & Fukhraj & Afghanaid & 5B, Gul Mohar Road, U/T & 841083 \\
\hline 5. & Massoda & $\mathrm{AGHCO}$ & 106, St.5, H-4,Ph-2 & 811342 \\
\hline 6. & Zakia & AIL & Arbab Road & 42697 \\
\hline 7. & Parwin & AIL & Arbab Road & 42697 \\
\hline 8. & Nelofar & AMRAN & 306, 3rd Floor, Arbab Rd Gulhaji Plaza & 845446 \\
\hline 9. & Diana Ibrahimi & $\mathrm{ANCB}$ & 25 Chinar Road & 43476 \\
\hline 10. & Eng Mehria & ATC & $45 \mathrm{D}-4$, old Jamrud Rd, U/T & 40412 \\
\hline 11. & Eng. Aqela & AWDP & $\mathrm{H \#} \mathrm{291,} \mathrm{St} \mathrm{25,} \mathrm{Ph} 1$ D4 & 812530 \\
\hline 12. & Marzia & AWDP & $\mathrm{H \#} \mathrm{291,} \mathrm{St} \mathrm{25,} \mathrm{Ph} 1$ D4 & 812530 \\
\hline 13. & Jamila Akbarzai & AWWD & $\mathrm{A} / 1$, New Defence Colony,opp police station & 843497 \\
\hline 14. & Partaw Naderi & $\mathrm{BBC}$ & 8 Abdara Road & 842320 \\
\hline 15. & Fawzia & CARE & 6 park.Lne, Park Road, U/T & 40614 \\
\hline 16. & Shenky & $\mathrm{CCA}$ & $\mathrm{H \#} \mathrm{4,} \mathrm{Sector} \mathrm{P-1,} \mathrm{Ph-4,} \mathrm{oppoiste} \mathrm{PDA}$ & 816386 \\
\hline 17. & Asma & $\mathrm{CCA}$ & H\# 4, Sector P-1, Ph-4, oppoiste PDA & 816386 \\
\hline 18. & Adela & $\mathrm{HCl}$ & 39-D, S.J. Afghani Rd, U/T, Peshawar & 840524 \\
\hline 19. & Saliha & IRC/FEP & 26-B, Circular Road, U/T & 841723 \\
\hline 20. & Khadija & IRC/FEP & 26-B, Circular Road, U/T & 841723 \\
\hline 21. & Dr. Shakilla & IRC/FEP & 26-B, Circular Road, U/T & 841723 \\
\hline 22. & Palwasha & IRFAN Center & & 817970 \\
\hline 23. & Malalai & Khadija K. School & Tahkal Paeen & --- \\
\hline 24. & Khorshid Noori & NAC & 21F, KKK Road,U/T & 43717 \\
\hline 25. & Homa Zafer & ROAOW & Street 9. Jamrud Road, Shaheen Town. & 844758 \\
\hline 26. & Sohaila Yarzad & SAS. Belgium & ITC building, 3-1, $\mathrm{Ph}-5$ & $812456-7$ \\
\hline 27. & Hawa Majid & SCA & 24/DE-Chinar Rd University & 814772 \\
\hline 28. & Ruqia & Takharistan School & Board & 41252 \\
\hline 29. & Carol Le Duc & UNICEF & 17/B, Abdara Rd, U/T, Peshawar & 43669 \\
\hline 30. & Niloufar & UNICEF & 17/B, Abdara Rd, U/T, Peshawar & 43669 \\
\hline 31. & Hadia & UNOCHA & 20D/A, Circular Road, U/T & 41131 \\
\hline 32. & Nasreen & VSB & St. 10, Shaheen Town & 818514 \\
\hline
\end{tabular}




\section{LIST OF MATERIALS \\ On \\ VIOLENCE AGAINST WOMEN AND GIRLS}

Name:

Organization:

(1) AVAILABLE FOR PHOTOCOPYING

- A new model of masculinity to stop violence against girls and women

- $\quad$ Arms and the man

- Courting Justice: farhat's story

- $\quad$ CRC Articles on Violence against Children

- $\quad$ Creating Violence-free families

- Domestic Violence towards women

- Exploitation of women in Sindh

- The impact of Domestic Violence on Children

- $\quad$ Trafficking in Nepal

- Violence against women: to resist is our constitutional obligation

- Why Karate for ladies and children

- Women Commentary

- Working with men and boys to challenge sexism and end men's violence

(2) AVAILABLE TO BE COPIED

- $\quad$ Promise kept, promise broken?

- $\quad$ The Initiatives for Legal Literacy/Legal Awareness

- Atlas of South Asian Children and Women

- Non-Commercial Sexual A'buse of Children

- The United Nations Convention on the Elimination of All forms of Discrimination against Women

- $\quad$ Voice Against Women: What will physicians do to stop it?

- $\quad$ Voices of South Asian Women

Note: a) Please make a thick mark in front of the articles you wish to have or borrow.

b) Do not forget to put your name and organization. 
Feedback Form

Name:

Organization:

1) What is your opinion about today's meeting on domestic violence? Were you interested? Did you hear anything which was new to you? What was most interesting for you?

2) Had you participated at any meetings on this issue before? If yes, when and what was said? What was the result?

3) What are your own thoughts on this issue, how relevant do you think it is to your work? Is it a priority for you or for your community?

4) Do you have any information on domestic violence based on your personal, academic or professional work? Have you ever faced it as a problem or issue in your life, among people you know or your work?

5) What would you like to do to end domestic violence, as an individual, as a member of your organization and your community? PIs. provide specific comments.

6) Would you like to see the AWN getting involved in this subject? If yes, pls. provide concrete suggestions.

7) Would you want to contribute to any programme addressing domestic violence? In what capacity or in what way?

8) What would yoú advise people/organizations who would want to begin some work on domestic violence?

Pls. feel free to write on additional paper, should the above space not be enough.

Please attach any printed material you might have on domestic violence. 


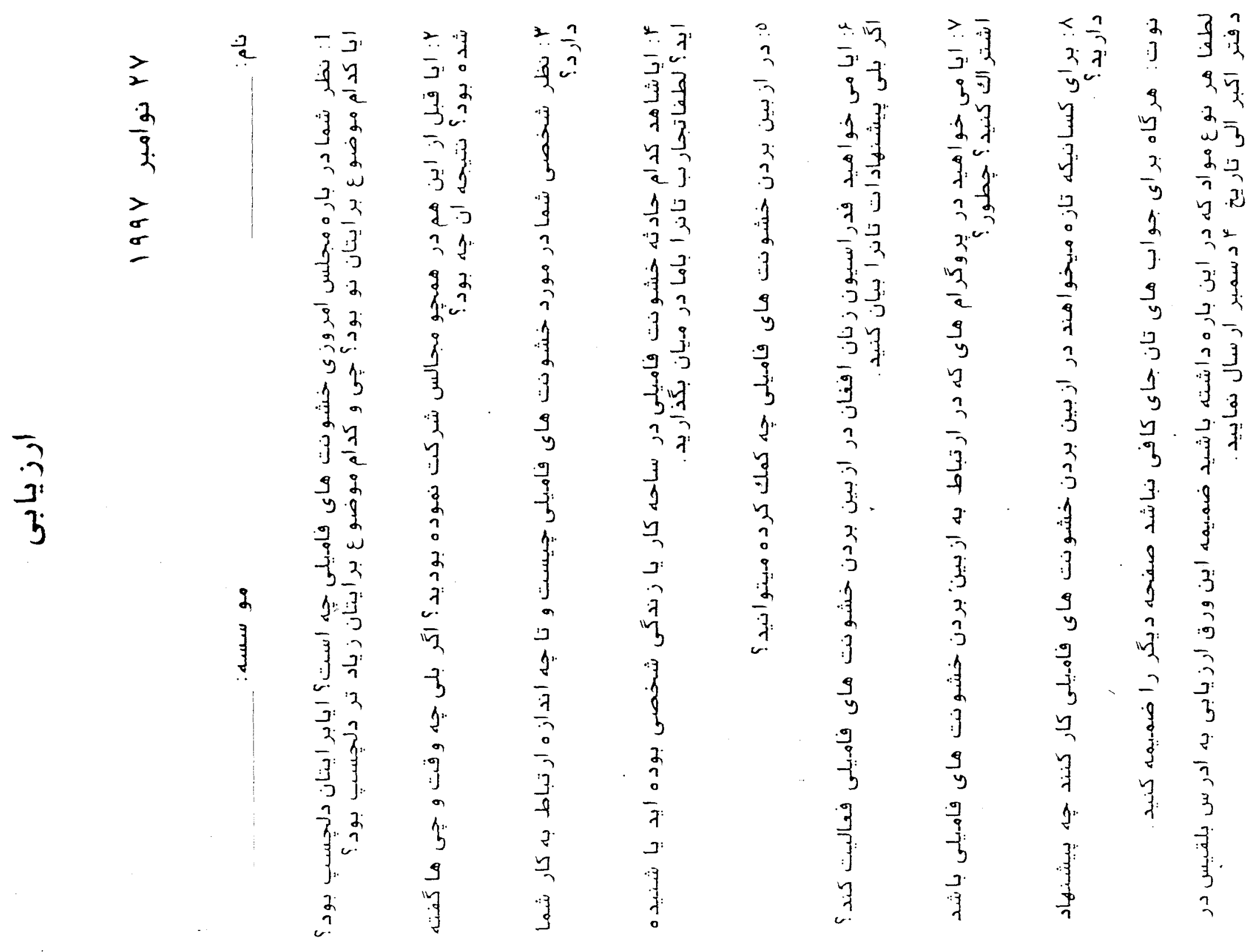




\section{Views on Domestic Violence ${ }^{1}$}

How Was the VAW Meeting of 27 Nov.97?

- Good/interesting/useful meeting - very relevant/important for Afghanistan.

- It would have been better if were asked ahead of time to collect/present information on this issue at the Meeting.

- $\quad$ First meeting on VAW ever attended.

- $\quad$ Need to invite more men to attend such meetings.

- $\quad$ Learned about new forms of VAW/their prevalence in Region - realized how serious the issue is .

- Very interesting BUT what is ever done in the world about VAW - look at Bosnia, Algeria.

What should be done to stop VAW?

- Urgent action needed.

- Greater advocacy\&awareness raising on VAW through media\&meetings.

- Lobby for Women's Rights

- Improve education and economic situation.

- Negọtiations with families, professional counseling.

- Brainstorming on what to do.

- Integrate into other actvts.

- $\quad$ Should be on agenda of Afghan Women's Network

- $\quad$ Personal commitment -among friends, family...

- $\quad$ Organize women in communities

- $\quad$ Provision of training onVAW

- Develop video/dramas on these issues

- Collect testimonies, case-studies

- Marital counseling

- Studying Islamic rights of women

- Organizing volunteer groups to contact families on these issues

Examples of VAW you are aware of:

Attempted rape of 14 year old girl in 1992 in Kabul by armed men.

Two sisters in Kabul whose father had lost them in gambling. They committed suicide rather than be "handed over". One died and the other was paralyzed.

${ }^{1}$ Based on six questionnaires returned so far. Questionnaires were distributed at Meeting of 27 November 1997. However, as they were distributed at the end of the Meeting, some participants had already left. Others have not returned them yet. Have put together several related questions/answers under one heading. 
- VAW based on ethnic, regional...differences, as result of war (rape by Hezb e Wahdat and Jamiat).

Example of pregnant woman beaten by her husband and her child born abnormal.

- $\quad$ Example of forced marriage/marriages promised at birth 


\section{THE KATHMANDU COMMTTMENT ON ENDING VIOILECE AGAINST WOMEN AND GIRLS IN SOUTH 1.514}

We women and men gathered as participants at the Meeting on Ending Violence against Women and Girls in South Asia held in Kathmandu, Nepal from 21 to 24 October 1997, organized by UNICEF, Regional Office South Asia with UNIFEM South Asia Regional Office, do hereby commit ourselves to that end

While recognizing that violence against all segments of society including children is a serious and growing problem in our times and in this region, we nevertheless statc that the issue of violence against women and girls has been largely ignored.

We come from countries in South Asia with a diversity of political situations, lawss, institutions, cultures and traditions. Yet the anguish of violence is a common problem that debilitates and threatens all women and girls, manifesting itself in similar and different ways, being rooted in gender inequality, discrimination, and patriarchal value systems and son preference.

Al forms of violence against women and girls, whether physical. scxual, psychological or others, including those perpetrated under conflict situations, are a gross vinlation of their individual human rights, as well as a major impeding factor for the equitable and sustimable development of our countrics. They are an extreme manifestation of the unequal power relations and unequal distribution of resources between men and women within the family, community, work place, in the political, cconomic, legal and educational systems and the State.

For too long women and girls have been forced to suffer violence silently in their families and communitics, in the work place, in public spaces, within public service institutions and through the legal system. They the victims of gross violence and infringement of their hodily integrity and basic human rights are stigmatized, victimized and blamed by societies affected by violence, inequalities and contradictions. Our silence has made us accomplices of this violence, even passive perpetrators.

Our first commitment as human beings concerned to build a gends violence free society is, therefore, $10 \mathrm{cnd}$ the conspiracy of silence. We vow to recognize and expose the reality of violence against women and girls perpetrated within our families, communities, work places, professions, political formations and by State action as well as inaction. It is only through such an open and participatory approach that we can bring society to deal honestly with the problem and ensure justice and support to the victims and the enforcement of the severest sanctions against the perpetrators.

We call upon our governments to honour the commitments on fiundamental rights they have made in their national constitutions and as State Parties to the Convention on the Elimination of All Forms of Discrimination against Women (CEDAW) and the Convention on the Rights of the Child (CRC) and other human rights treaties. We demand that they internalize the standards that they have 
ratified, at the national level. We commit ourselves to using the mechanisms provided in these constitutional and international instruments to ensure the accountability of our governments to climinate violence against women and girls and achieve equal rights between women and men in both public and private spheres. In this respect, we shall strive especially to achieve adequate proiection through the legal system for women and girls who are the victims of violence and the provision of all other nccessary support services. This will include lobbying for policies on compulsory eduration. access to health care and allocation of adequate resources for these purposes and for law enforcement. 'This will also include efforts to bring knowledge of legal rights to every citizen of our countrics through educational strategies and giving access to justice through the legal system. Since violence against women is also exacerbated in conditions of poverty, we shall cany out proaclive advocacy for appropriate policies and programmes that will help alleviate poverty and meet basic needs as entitlement.

We shall lobby with our governments to withdraw reservations to CEDAW and CRC wherever applicable and promote legal, policy and social changes that will help to intemalize their standards in our countries. Recognizing that cultures and traditions are never static and that they have bcen transformed through the centuries, we commit ourselves to promoting positive changes in accordance with the letter and spirit of the UN Declaration on Violence Aganst Women, the Beijing Platform for Action and the Beijing Declaration. We shall endeavour to irengthen traditions that conform with values of gender equality and non-violence, and eliminate these which entrench gender discrimination and result in denial of the human rights of women and gits.

We also call upon the South Asia Association for Regional Cooperation (SAARC) and the agencies of the United Nations system to play an active role in advocating for a gender viulence free socicty in South Asia and to assist governments, educational institutions, other opinion and value generating institutions and non-govemmental organizations in our countries towards that end. We in particular call upon SAARC and its member countries to fulfill and build upon the commitments of the Male Summit (1997) to adopt a Regional Convention and to demand and ensure regional and bilateral co-opcration for stringent law enforcement and strict prevention of cross border and incountry trafficking of wornen and children.

We recognize that the family itself often promotes and perpetuates gender based violence, through the differential treatment given to girls and boys from conception and birth by all members of the family. We shall endeavour to promote gender equality in the family, so that this key institution in our countries becomes a source of support for its members and creates a co-operative and nurturing environment. This requires the involvement of a number of institutions in the rcconstruction of the nature and functions of the family. We call upon the State to recognize its duty to protect human rights by protecting women and children against any act of violence that occurs in the family

As schools often perpetuate the status quo on gender relations we urge that policy makers, educators, tcachers and children develop gender sensitive curriculum and teacher training methods. We recommend life skills training with special reference to gender violence and puberty related issues 
using participatory and intcractive methods of teaching and communication We urge that schools interact closely with the communities in which they are located

Wo women and men recognize that, without the active particimation of men, we cannot achieve our goal of climinating violence against women and girls. We sholl strive as individuals, as parents, as educators and as opinion formers to promote new, positive midtels of masculinities and femininitics, so that boys and young men will grow up realizing their own potential as caring human beings committed to respecting the rights of women and girls as equal partners in their fanilies, communities and societies.

We rccognize the potential of children, both girls and boys, to interact with one another and with adults in preventing and responding to violence against women and cluldien and we shall endeavour as parents, educators and individuals to support and develop programmes to ensure the paticipation of children and youth to end gender based violence.

Recognizing youth as a group with distinct needs, issues and capabilities, we commit in accordance with the letter and spirit of the Convention on the Rights of the Child to promote their participation as facilitators and mobilizers for the elimination of gender based violence. We shail build and support networks of young people, encourage discussion and undersiniting of issucs of gender violence, unequal power relations and sexuality among the youth through barious ongoing training and outrcach programmes in schools and other institutions and though rarticipatory research on issues relating to them.

We realize that the media is an integral part of our lives. Acknowlenging its tremendous force to change mind sets and mould public opinion, we appeal to all forms of nedia to play a proactive. investigative and supportive role in our struggle against gender based violence. We urge responsible and scnsitive handling of such events. We believe that this is only possible if media is given access to information as a matter of right and the right to privacy of victims is respected by media. We also call upon the media to promote and portray positive gender images and confront stereotypes and discrimination.

We, individually and collectively, within our countries and in the region, commit ourselves to work towards eliminating gender bias and violence in our professions and work places and creating an environment and developing competence and sensitivity that will help to build a gender violence free conmunity and society. Wé also undertake to work within our professions to develop and/or enforce a professional code of ethics that will prevent and respond to the problem of gender based violence and towards this end we commit ourselves as follows:

- As legal professionals and those involved in the formulation and enforcement of laws, we shall advocate and contribute to the reform of discriminatory laws and to the sensitive and effective enforcement of law, promoting awareness of the law and its proactive use in countering violence against women and girls. 
- As medical professionals, we shall advocate and work towards increasing awareness and recognition among all health personnel, about acts of violence against women and children and to take appropriate, preventive, curative, rehabilitative medico-legal action.

- As exucators, we shall advocate and work towards education for expality, non-violence and peace, support research and training on gender violence, tegul hteracy, develop gender sensitive curriculum and pedagogical training

- As media professionals, we shall endeavour to portray and report on issues pertaining 10 violence against women and girls sensitively, vividly and honestly, keeping in mind that the viclim should not be further victimized through our reportage, create awareness on gender issucs and the need for social action against all forms of gender violence.

- Wewriters, rccognizing that we cannot be expected to write according to a certain agenda, but also realizing the power of the word and the consequences of reinforcing gender stereotypes through writings, commit ourselves to the creation of a gender violence frec society and heighten awareness, through our writings, of the issues of gender violence and the value system which sustains it.

- We the perforning artists and cultural activists, commit ourseives to promote the values of a gender violence free society and bring about attitudinal changes through our work. We also commit ourselves to forcefully resist any attempts to place restrictions on freedom of cultural cxpression, espccially of women and cultural workers, placed by the governments or other pressure groups in any country of the region

- We men, realizing that no sustainable change can take place unless we give up the entrcnched idcas of male superiority, commit ourselves to devising new role models of masculinity. We shall endeavour to "take off the armour" and move towards becoming a more developed and complete being. We urge international bodies to focus on and explore the destructive consequences of patriarchy.

We resolve to build larger alliances involving the women's movement, sensitive professionals from the media, the arts and cultural spheres, institutions of learning. the health and the legal system and political groups across our national borders and co-ordinate our efforts in order to build the necessary synergy to end violence against women and children in South Asia. We appeal to our governments and the UN system to facilitate and support these efforts.

We recognize the complexity of the problem of violence against women and girls and that it requires a range of interventions at the level of the family, the community and the State. We, thercfore, commit ourselves to promoting the necessary laws, policies and allitudinal changes using inter-disciplinary approaches that will help us to network, share and exchange, using all communication tools at our disposal, and support each other's endeavours as citizens, officials, NGOs, professionals and human beings. 







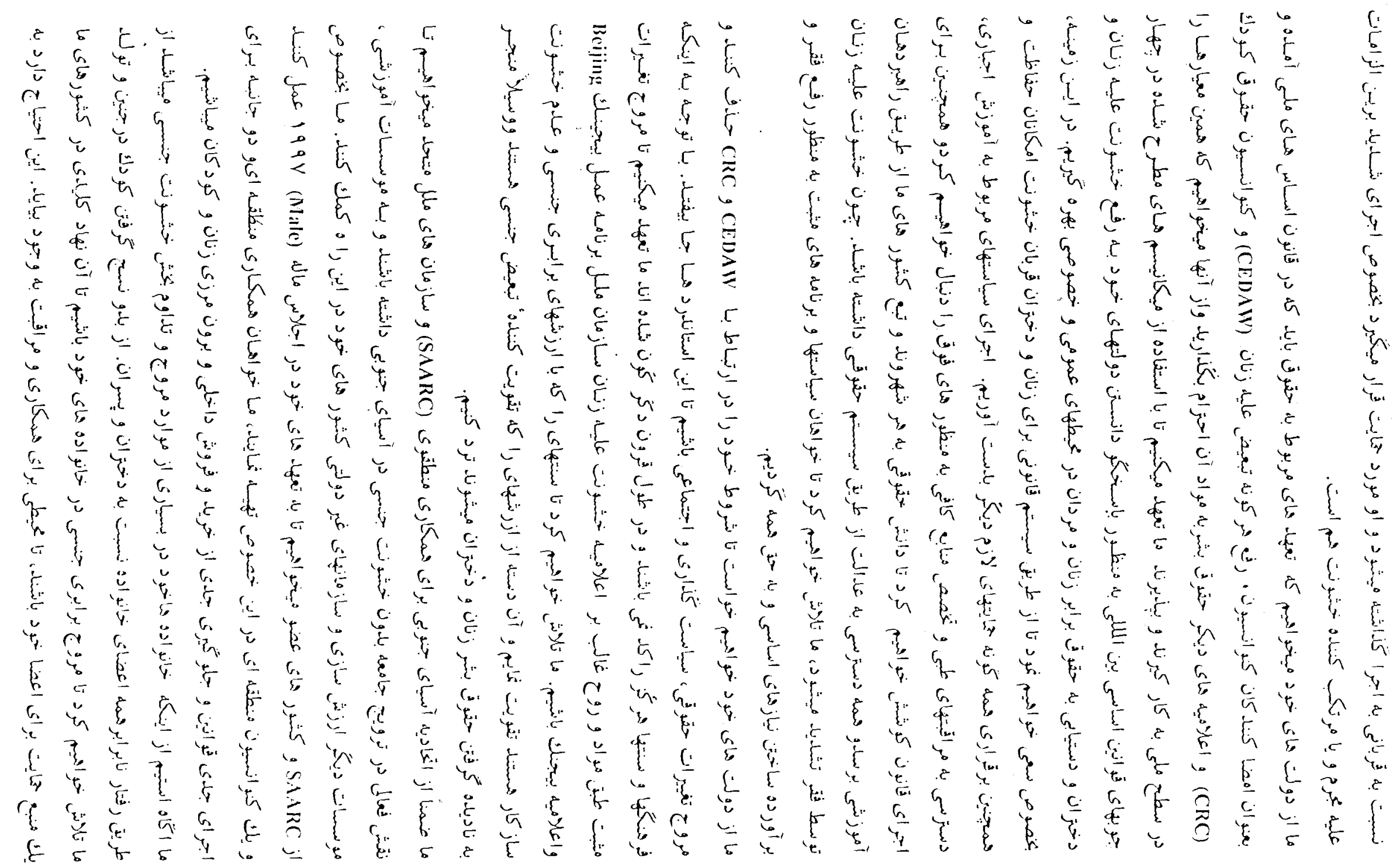




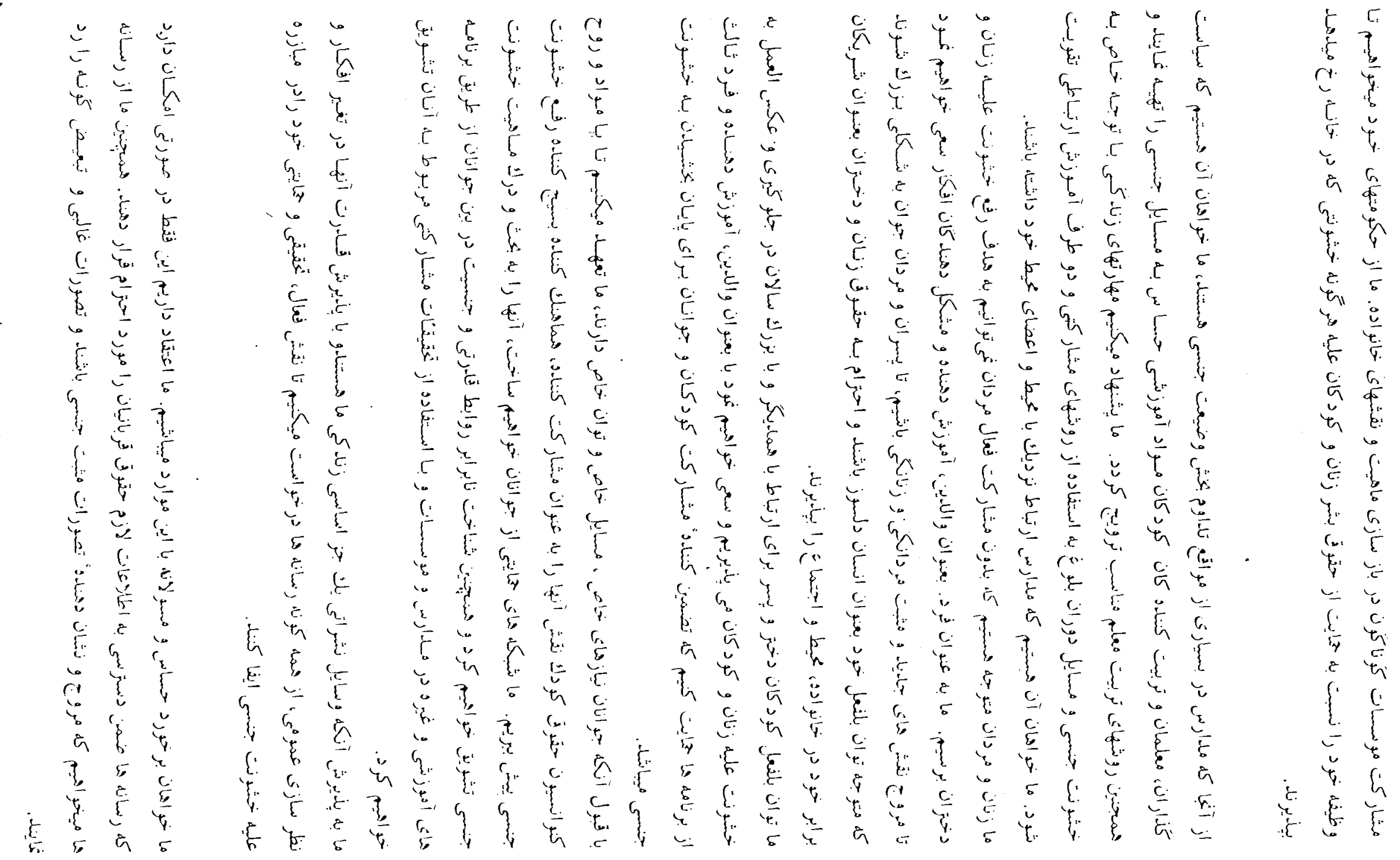




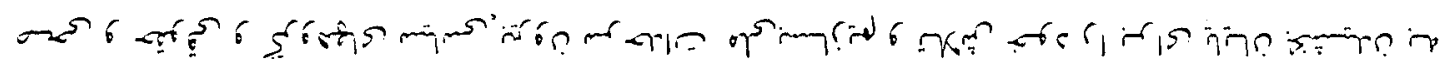

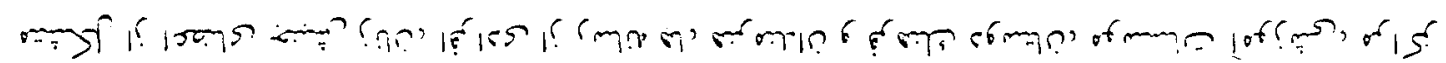

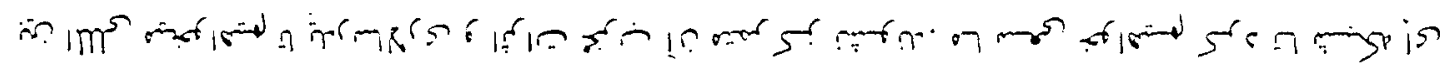

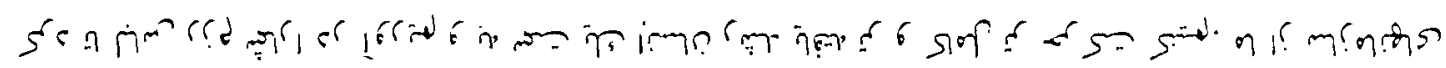
له

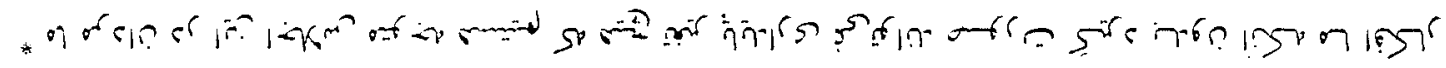

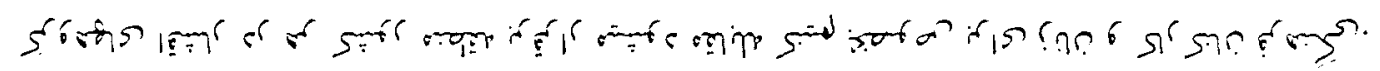

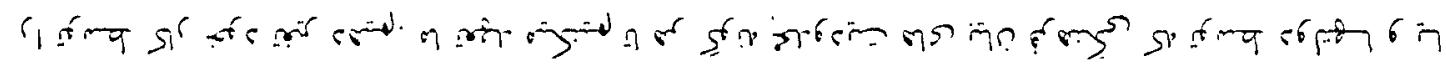

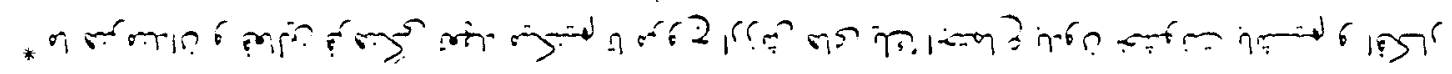

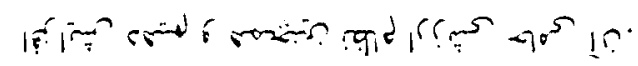

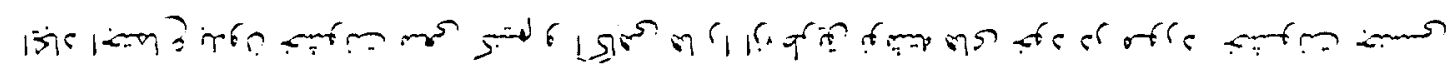
كים * 0 "

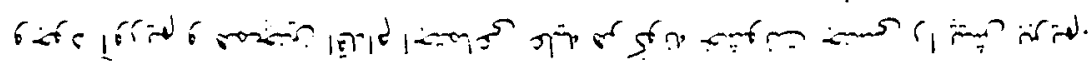

然

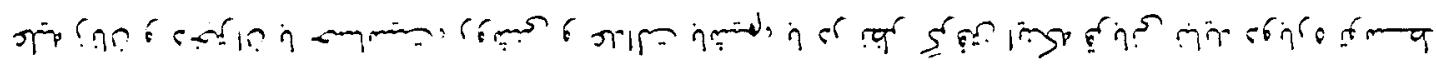

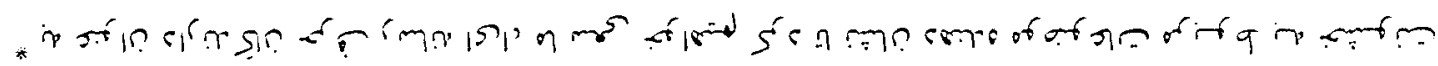
cremats

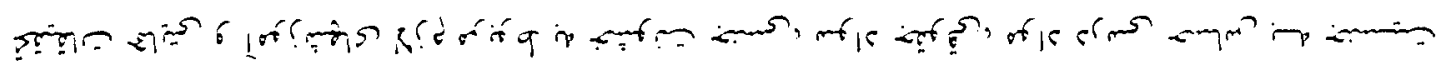

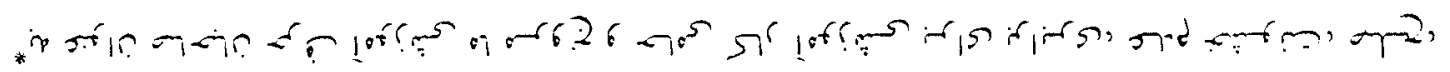

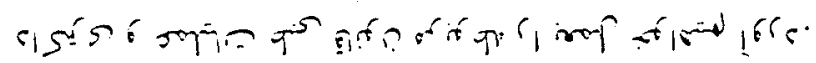

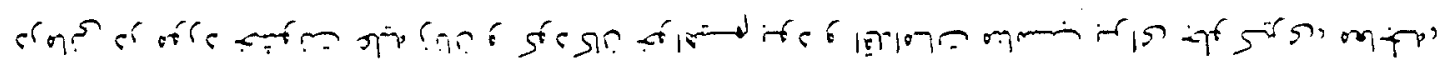

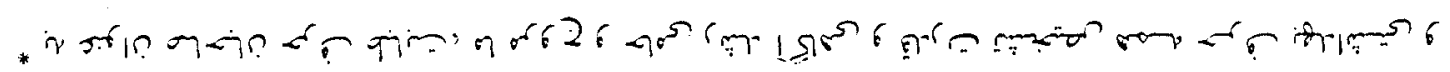
"ripin

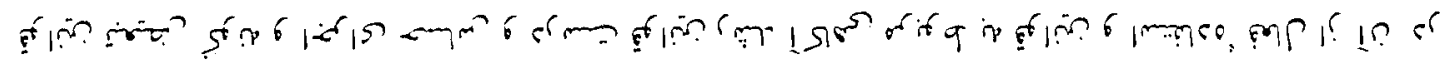
* * की

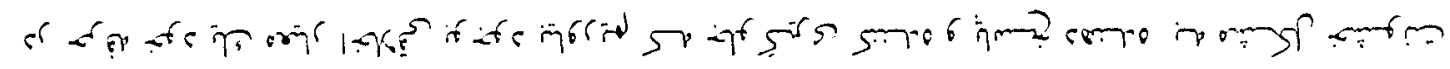
له

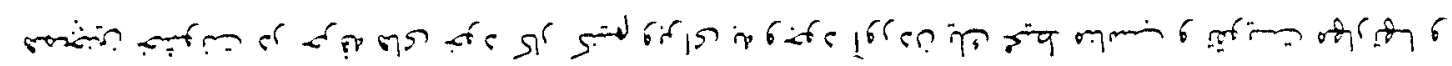

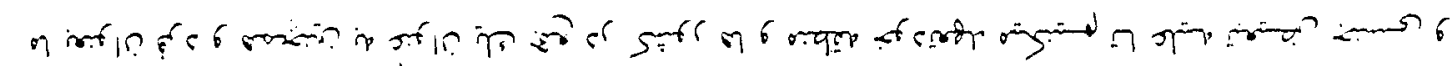




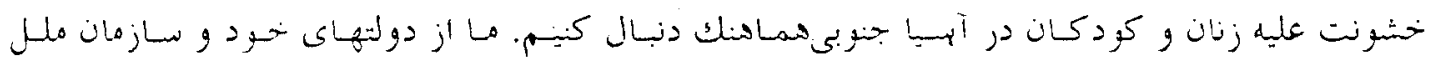

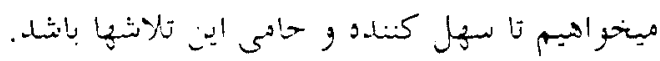

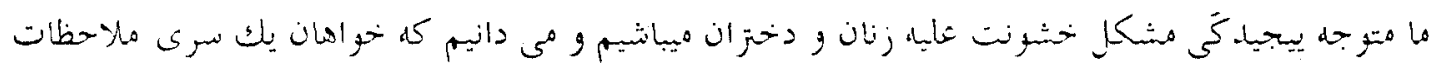

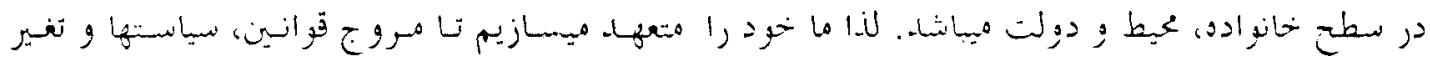

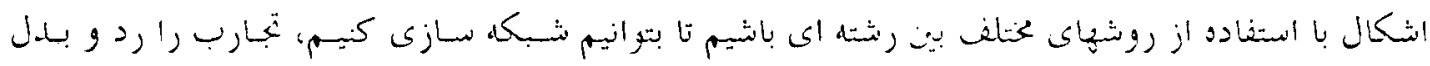

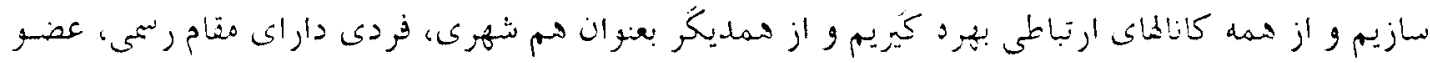

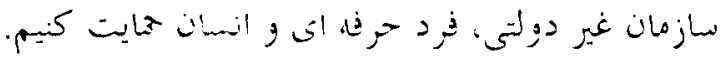




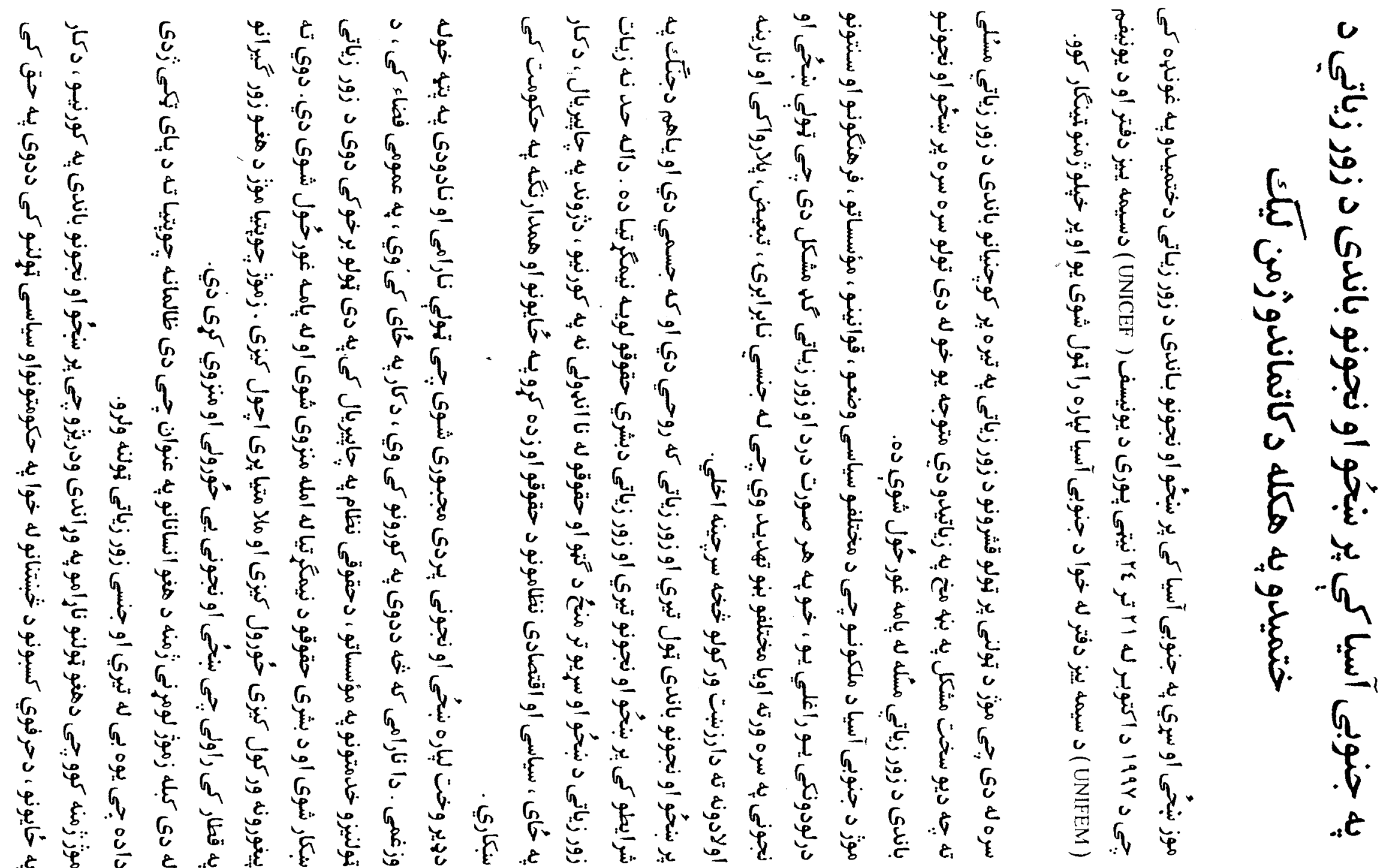




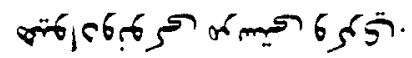

ת

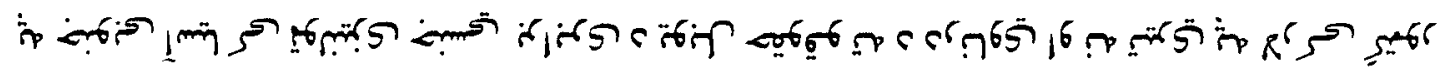

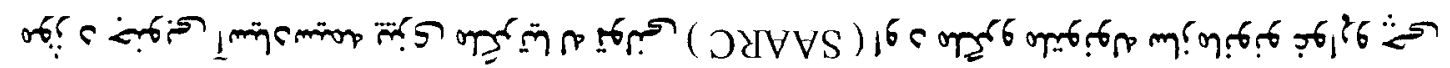

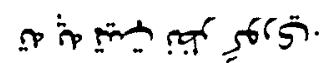

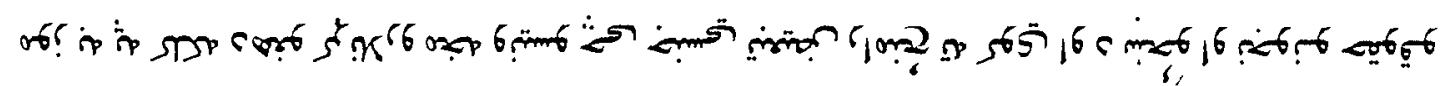
药

ه

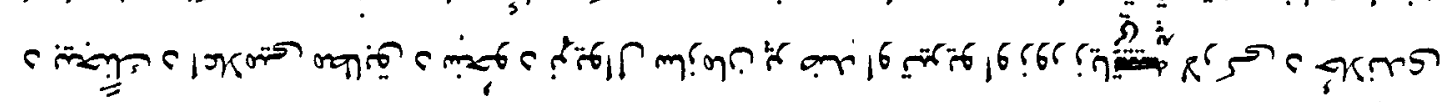

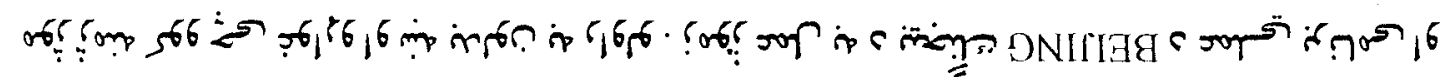

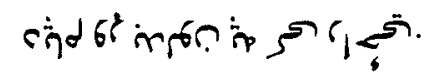

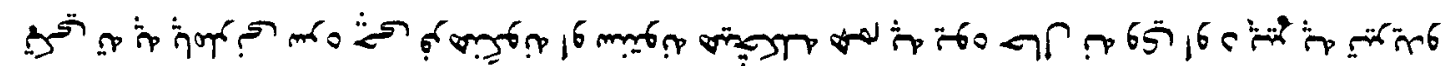

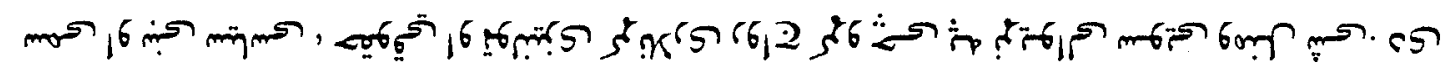

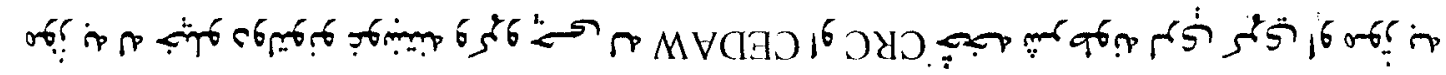

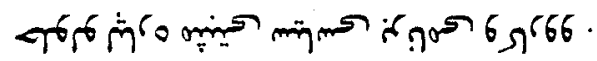

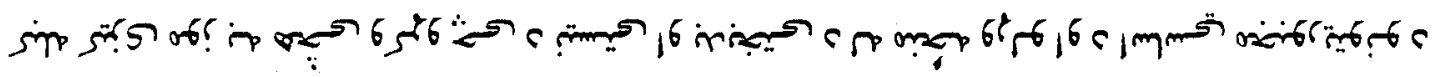

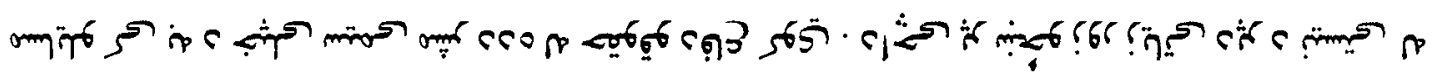

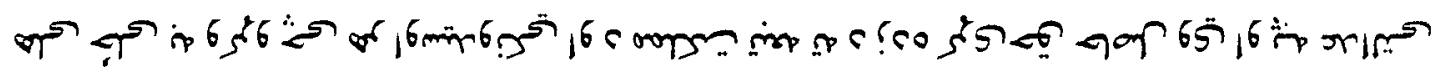

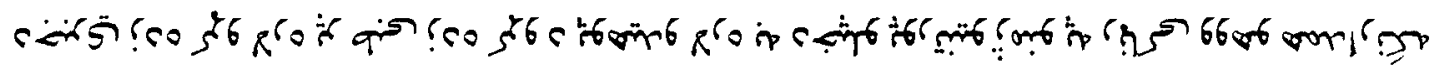
66 min 6 .

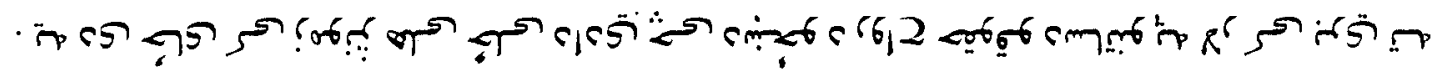

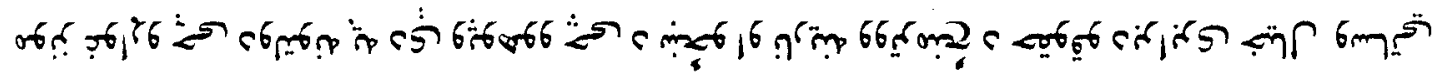

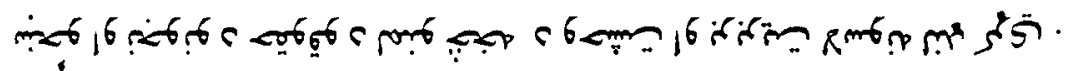

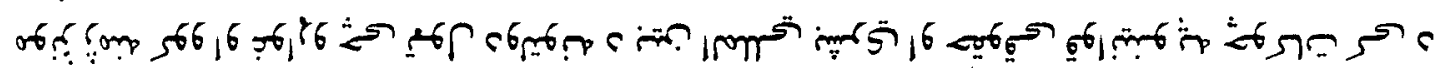
.

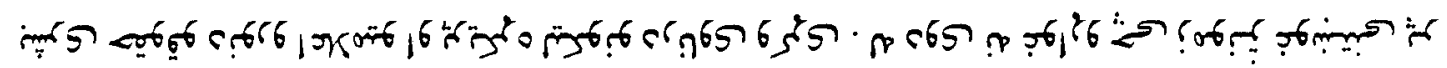

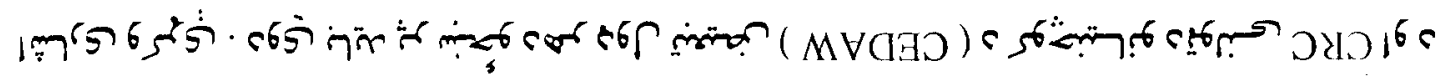

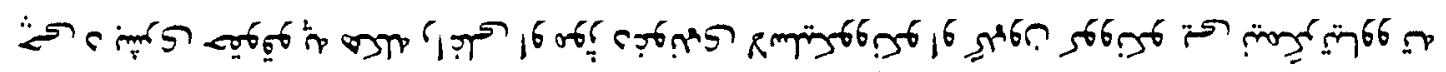
דיל

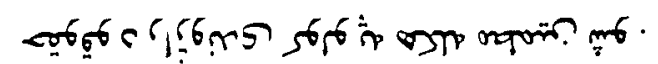

c 


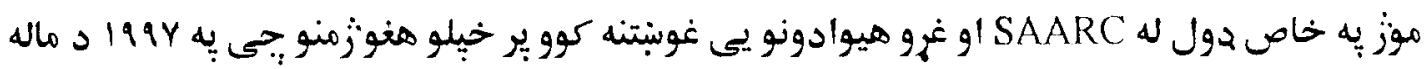

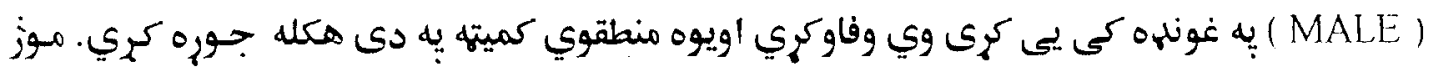

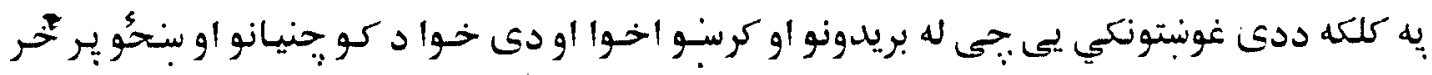

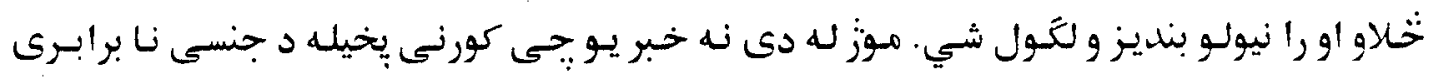

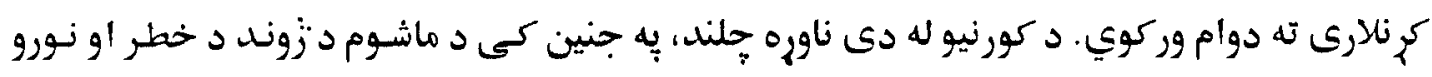

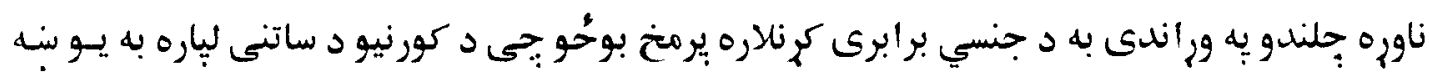

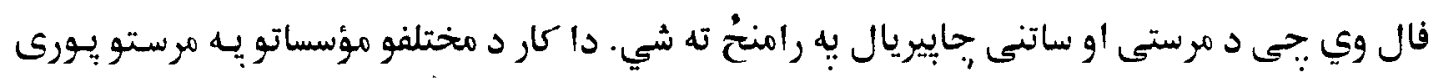

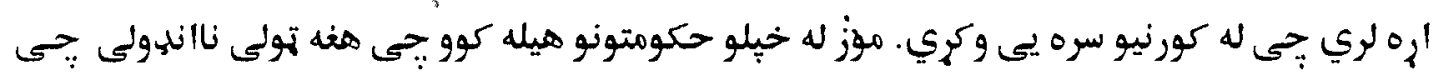

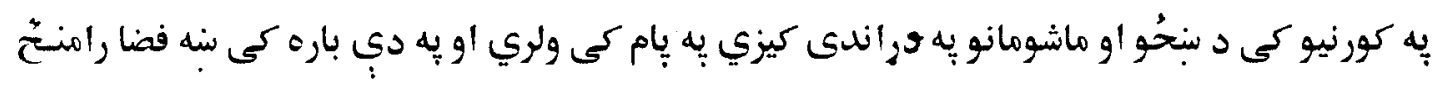

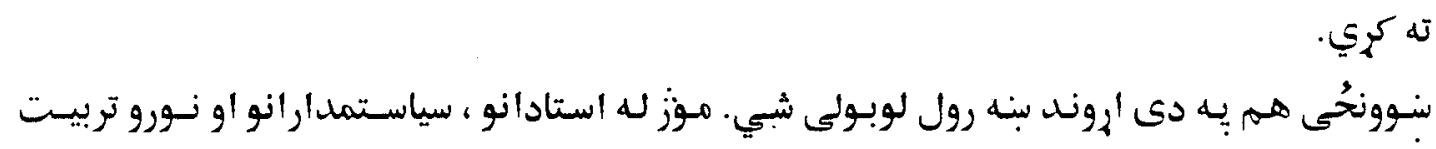

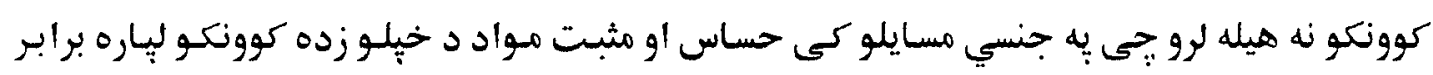

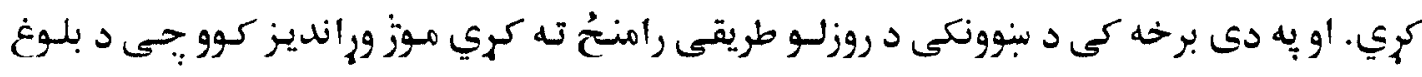

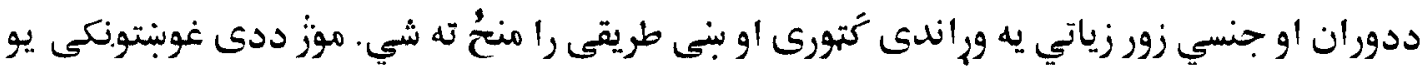

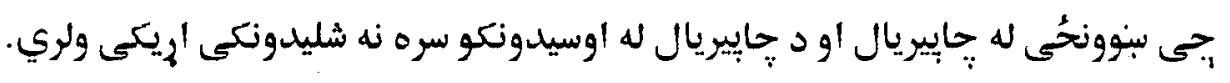

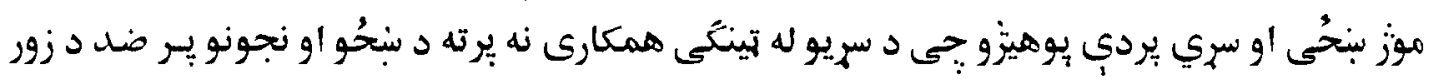

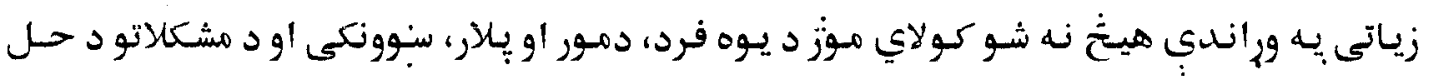

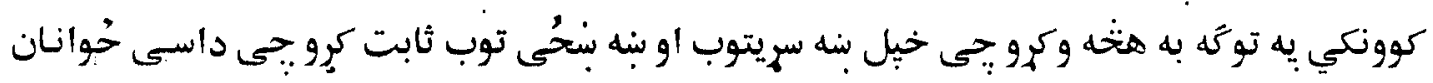

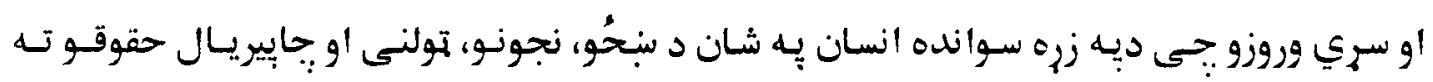

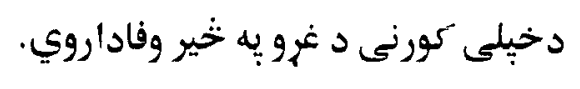

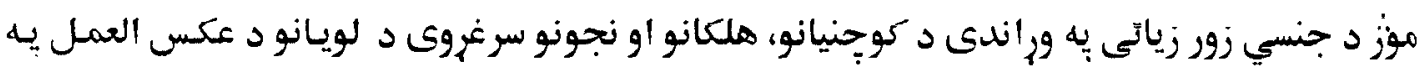

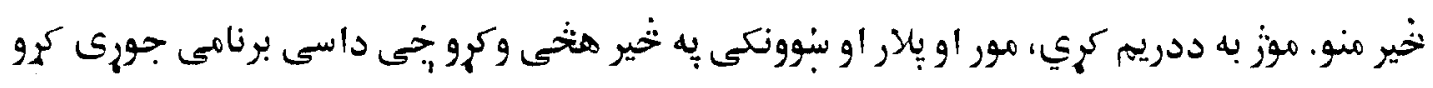
جحى جنسي نابربريو ته خاتمه وركي مئي

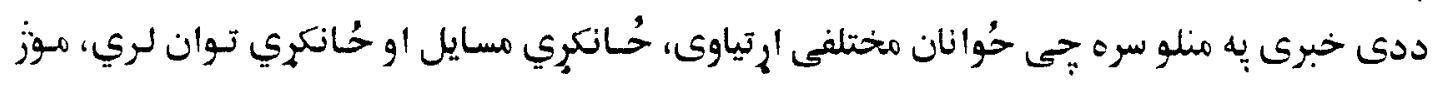

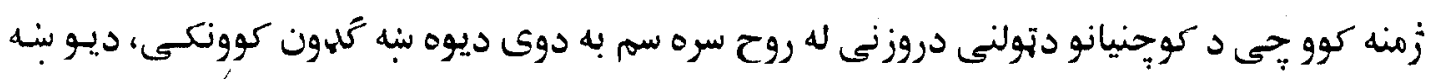

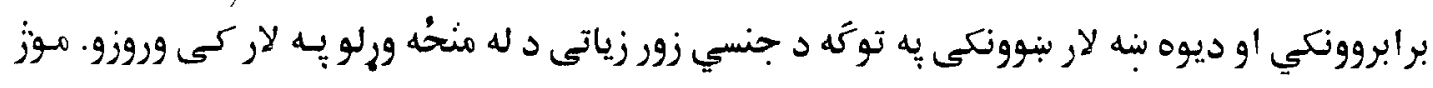

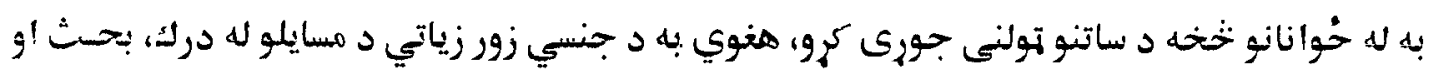

$$
\text { سمونى نه خبر كرو انو }
$$

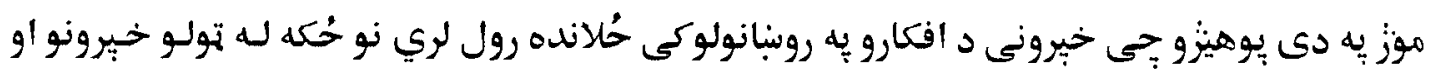

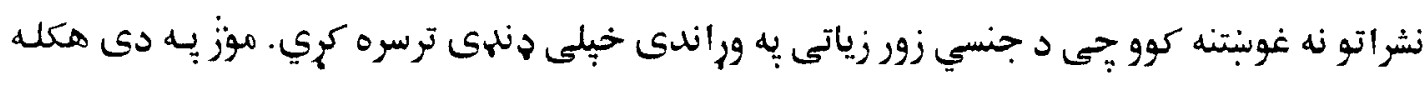

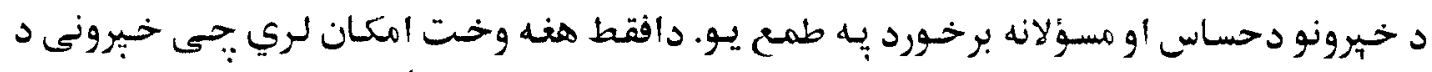




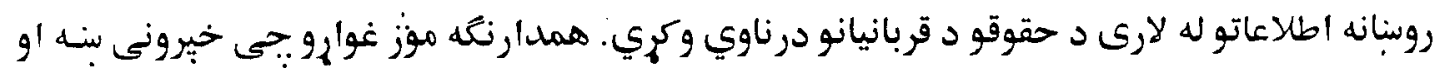

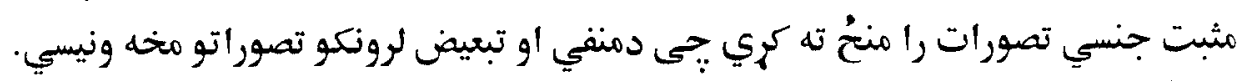

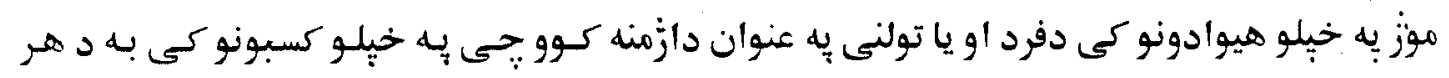

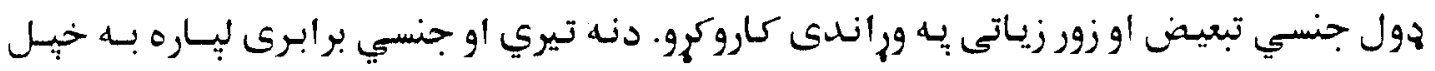

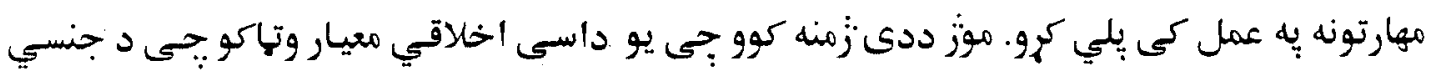
زور زياتى او نابربريو مخه نيسي.

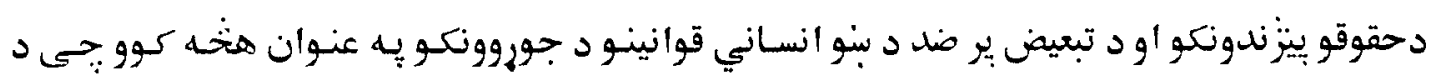

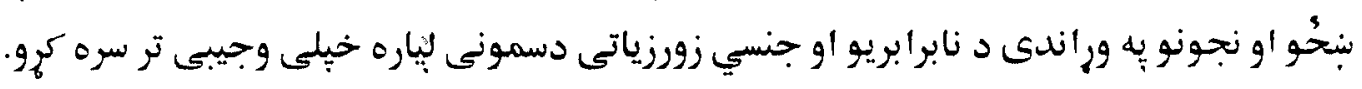

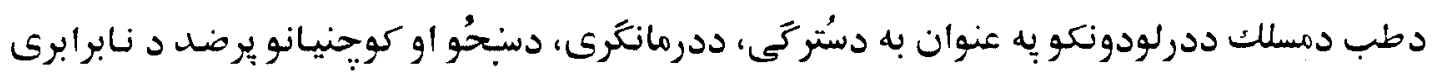

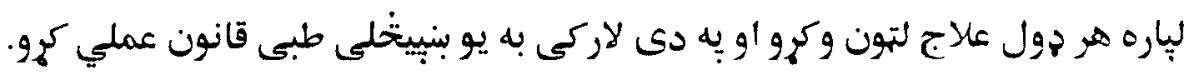

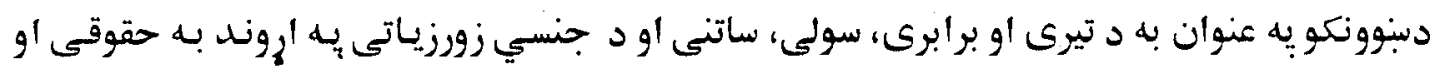

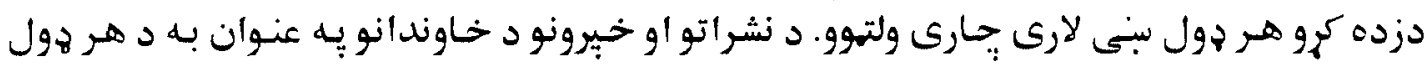

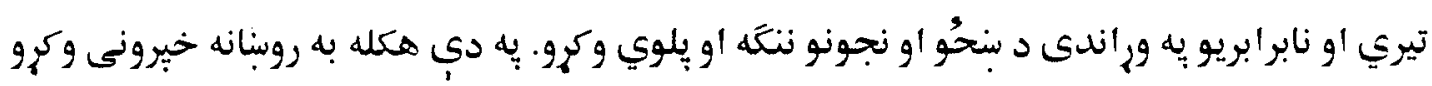

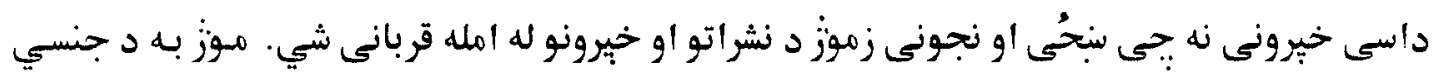

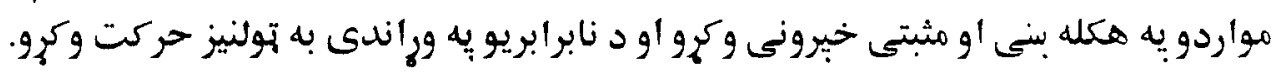

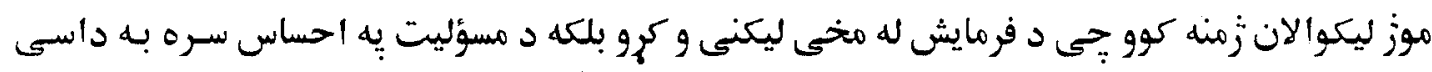

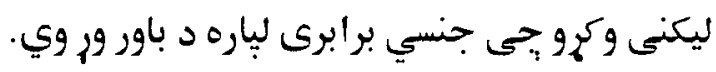

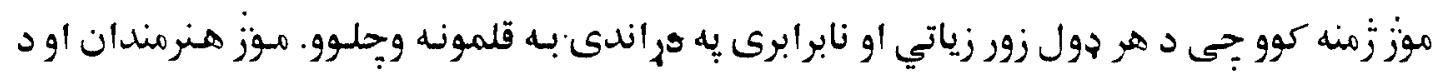

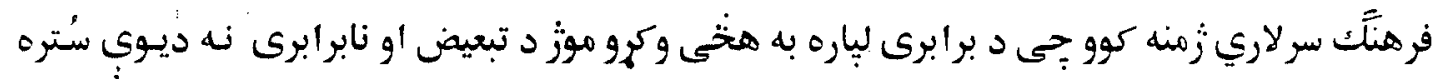

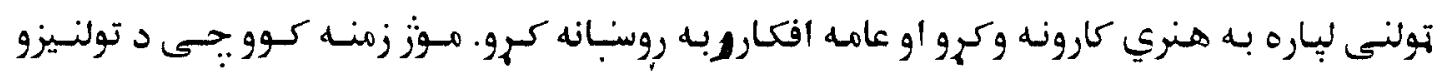

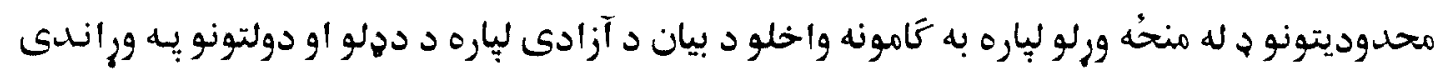

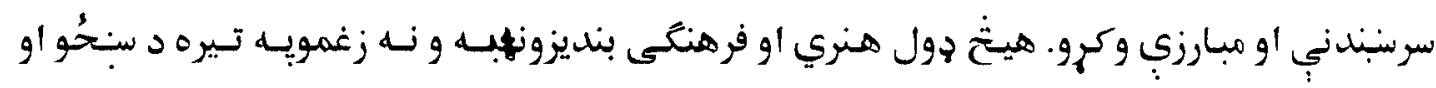

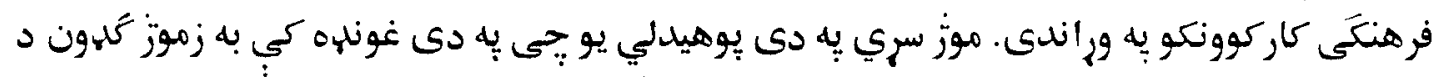

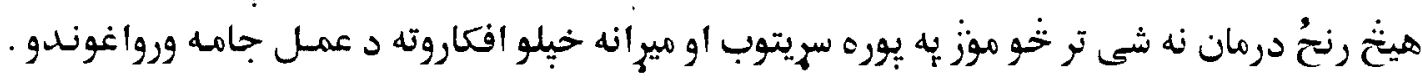

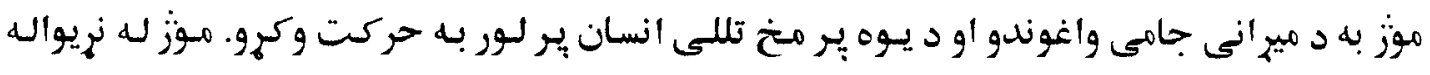

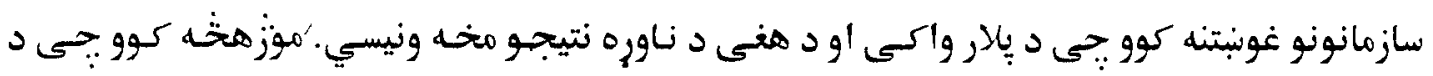

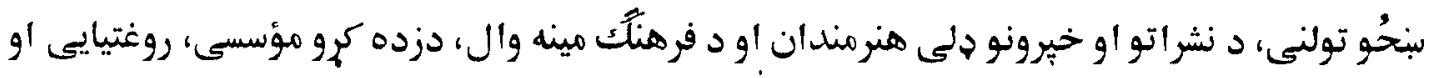

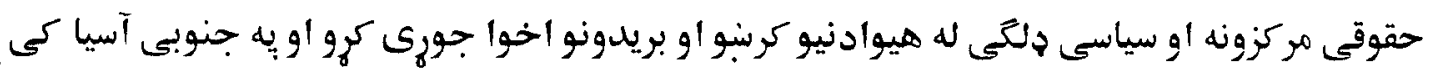

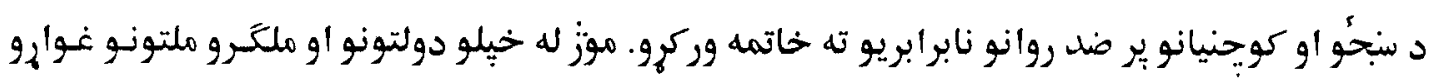


موز ير نسحو او نجونو باندى دزور زياتى نه راولارشويو مشكلاتو ته متوجه يو او يوهيزو :جى د كورنيو،

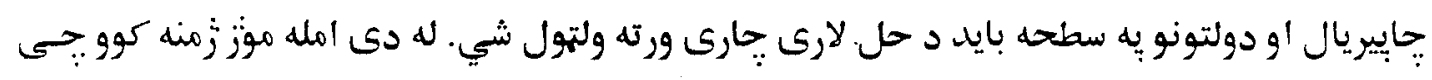

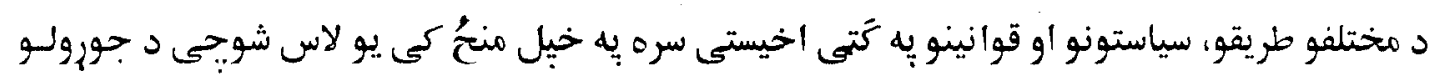

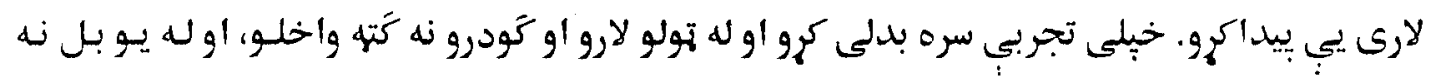

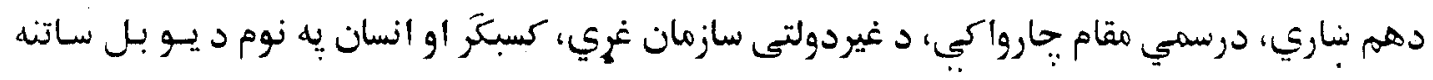

